\title{
Implementation of Youth Information and Counseling Centers Related to HIV/AIDS Prevention in a Junior High School in Bandung
}

\author{
Shifa Nadya Rahma, ${ }^{1}$ Insi Farisa Desy Arya, ${ }^{2}$ Rudi Wisaksana ${ }^{3}$ \\ ${ }^{1}$ Faculty of Medicine Universitas Padjadjaran, Indonesia, ${ }^{2}$ Department of Public Health Faculty \\ of Medicine Universitas Padjadjaran, Indonesia, ${ }^{3}$ Department of Internal Medicine Faculty of \\ Medicine Universitas Padjadjaran/Dr. Hasan Sadikin General Hospital, Bandung, Indonesia
}

\section{Abstract}

Background: Adolescents are the population group most at risk of human immunodeficiency virus (HIV) infection due to low knowledge about HIV/acquired immune deficiency syndrome (AIDS). The National Population and Family Planning Board (Badan Kependudukan dan Keluarga Berencana Nasional, BKKBN) has developed the Youth Information and Counseling Center (Pusat Informasi dan Konseling Remaja, PIK-R) Program as a forum for information and counseling services, one of which is about Adolescent Reproductive Health (ARH) including HIV/AIDS. This study aimed to explore whether the implementation of the programs related to HIV/AIDS prevention in adolescents, specifically in junior high school in Bandung City.

Methods: A qualitative descriptive study was carried out at a junior high school in Bandung in August 2018. This study used a purposive sampling technique and data were collected by conducting indepth interviews with nine program administrators who were then transcribed and coded based on the PIK-R management guidelines using the NVIV012 software, observing the program activities and documentations study which were then triangulated.

Results: Several indicators in the growing stage had been implemented according to the guidelines, consisting of mastering ARH education materials including HIV/AIDS, conducting activities in the form of providing materials and peer counseling although without a secretariat room, and establishing networks and partnerships.

Conclusions: The PIK-R program can be a media for preventing HIV/AIDS among junior high school students in Bandung regardless of resource limitations. Therefore, supports from BKKBN and the school itself is needed to improve the implementation of this program.

Keywords: Adolescent, HIV/AIDS,implementation, prevention, PIK-R

\section{Introduction}

According to data from the United Nations Programme on HIV and AIDS (UNAIDS) in 2016, there were 48,000 new human immunodeficiency virus (HIV) infections and 38,000 deaths from acquired immune deficiency syndrome (AIDS) in Indonesia. ${ }^{1}$ The duration from HIV infection to AIDS varies, but is usually around 8-11 years. ${ }^{2}$ The incidence of AIDS cases in Indonesia shows that the most cases are at the age of 20-29 years. ${ }^{3}$ Therefore, adolescents aged 10-19 years are the population group with the highest risk of contracting HIV infection. ${ }^{3}$ This is due to their low knowledge of HIV/AIDS. The 2012
Indonesian Demographic Health Survey (IDHS) shows that only $11.37 \%$ of young adults aged 15-24 in Indonesia had good knowledge of HIV prevention. ${ }^{1}$

The National Population and Family Planning Board (Badan Kependudukan dan Keluarga Berencana Nasional, BKKBN) has developed a program, called 'Planning Generation' (Generasi Berencana, GenRe), including the Youth Information and Counseling Center (Program Informasi Kesehatan Remaja, PIK-R). PIK-R is a forum for Family Life Planning for Adolescents which is managed from, by and for adolescents to provide information and counseling services, one of which is about Adolescent

Correspondence: Shifa Nadya Rahma, Faculty of Medicine, Universitas Padjajaran, Jalan Raya Bandung Sumedang KM 21, Jatinangor, Sumedang Indonesia, E-mail: shifanadyaa@gmail.com 
Reproductive Health (ARH), including HIV/ AIDS. The existence and role of PIK-R in the youth environment are very important in helping adolescents obtain comprehensive information and youth-friendly counseling services. ${ }^{4}$

The PIK-R program has been implemented in several junior high schools in Bandung since 2013. Guidelines for the management of PIK-R were published by BKKBN in 2012. ${ }^{4}$ However, according to the Population Control and Family Planning Services (Dinas Pengendalian Penduduk dan Keluarga Berencana, DPPKB) of Bandung, the implementation is still varied and has not based on existing guidelines.

Based on the PIK-R management guidelines, there are three stages in the implementation of PIK-R. The first stage is the formation stage which is called the Growing Stage (Tahap Tumbuh). Then in its development, the program moves to the Firm Stage (Tahap Tegar) and the last is the Upright Stage (Tahap Tegak), each of which has its own indicators, including (1)educational materials controlled by the Peer Educators, (2)activities undertaken, (3)facilities, infrastructure, and human resources, and (4)networks and partnerships. ${ }^{4}$ Researchers used indicators of growing stages in accordance with PIK-R management guidelines as a reference in this study. The aim of this study was to determine how the implementation of the PIK-R program was carried out in junior high school as a manifestation of the HIV/AIDS prevention program in adolescents in Bandung.

\section{Methods}

This research was a case study with a qualitative descriptive approach, conducted in August 2018 at a public junior high school (Sekolah Menengah Pertama Negeri, SMPN) in Bandung which had the PIK-R program. Schools that had been implementing the PIK-R program were asked to participate. According to the DPPKB of Bandung, there were four junior high schools in Bandung that had been implementing the PIK-R program, including SMPN 51, SMPN 39, SMPN 35, and SMP Plus Al-Ghifari. However, only SMPN 51 was still actively participating in this program based on site visits, thus, this school was further enrolled in the study. This study used the purposive sampling technique until there was saturation of the data. Data collection was carried out by structured interviews with program administrators based on the PIK-R management guidelines. The answers from the informants were recorded using a mobile phone voice recorder. Program activities were then observed when they introduced PIK-R activities and presented educational materials to new members. Consecutively, the study of documentation was carried out by examining documents such as the Decree for the Establishment and Implementation of PIK-R at SMPN 51 Bandung, the PIK-R Database and Organizational Profile, Application for Program Implementation Permits, and Training Participation Certificates.

Data analysis was performed using qualitative data processing software, (NVIVO12, QSR International USA). The recorded interviews were transcribed and then coded and categorized. The conclusion of the interview was triangulated with observation and documentation study. This research was approved by the Health Research Ethics Committee of Universitas Padjadjaran no. 494/UN6.KEP/EC/2018, as well as approval from the SMPN 51 Bandung.

\section{Results}

The informants of this research were 9 active PIK-R administrators consisting of 3 coaches, 1 chairman, 2 peer educators, 2 peer counselors, and 1 secretary.

The steps for establishing PIK-R include 1) A meeting of youth members for the formation of PIK-R and PIK-R management to discuss the importance of forming PIK-R and agree on its formation, 2)Consultation and coordination to obtain support/approval with local leaders regarding the plan to establish PIK-R (school principals), 3)Arrange the names and composition of the PIK-R management, 4) Develop a program of activities in accordance with the indicator Growing Stage PIK-R, and 5)Inaugurated the establishment of PIK-R which was strengthened by a Decree from the concerned PIK-R supervisor. ${ }^{4}$

The results of the interview showed that the PIK-R SMPN 51 Bandung was formed four years ago because it was appointed directly by the DPPKB of Bandung city to participate in the city-level PIK-R competition. This coincided with the need for schools to anticipate students from committing juvenile delinquency such as free sex, drug abuse, smoking, and others.

"Firs, it was formed because of the students' anticipation needs to avoid free sex, use of cigarettes, and drug abuse, whereas incidentally it was also appointed from the DPPKB. " (Co3)

The formation of the PIK-R was strengthened by the existence of a decree from 
Table 1 Informant Characteristics

\begin{tabular}{lcccc}
\hline \multicolumn{1}{c}{ Code } & Gender & Age (years old) & Position & Active Period (year) \\
\hline C1 & Female & 14 & Chairman & 1 \\
Co1 & Female & 41 & Coach & 4 \\
Co2 & Male & 42 & Coach & 4 \\
Co3 & Female & 56 & Coach & 4 \\
PE1 & Female & 14 & Peer Educators & 1 \\
PE2 & Male & 14 & Peer Educators & 1 \\
PC1 & Female & 15 & Peer Counselor & 1 \\
PC2 & Female & 14 & Peer Counselor & 1 \\
S1 & Female & 14 & Secretary & 1 \\
\hline
\end{tabular}

the current principal. The decree also attached the management structure of PIK-R SMPN 51 the year 2018 which consists of Patrons, namely the DPPKB of Bandung, the Person in Charge, namely the Principal of the SMPN 51 Bandung, the supervisor of the PIK-R in Bandung, the Rancasari District health center, the Rancasari Police, the Family Planning Coordinator in the District of Rancasari, and the Deputy Head of Student Affairs, four mentors from the Counseling Teacher, one chairperson, one deputy chairperson, two secretaries, one treasurer, three peer educators, two peer counselors, one life skills section, one documentation section, and one public relation section which was also in accordance with the wall magazine management structure made by PIK-R members. The results of this study indicated that the steps for establishing PIK-R at SMPN 51 Bandung were in accordance with the PIK-R management guidelines.

The PIK-R Growing Stage program activities consist of GenRe materials controlled by Peer Educators, which are 8 Family Functions, Maturity of Marriage Age, ARHTRIAD (HIV/ AIDS, sexuality, and drugs), and Life Skills. ${ }^{4}$ Based on the results of this study, PIK-R members mastered various PIK-R materials, especially the ARHTriad, prevention of early marriage, and other adolescent problems. Materials were obtained from various sources such as the internet, books, counseling classes, and the gathering for PIK-R members.

"The main material is about the ARHTriad: HIV/AIDS, Sex, Drugs. " (C1)

"The materials were about adolescent issues, $H I V$, the dangers of smoking, premarital sex and pregnancy, and drugs." (PC2)

The main activities of PIK-R in its the growing stage are to increase awareness in the school environment by using print media such as wall magazines, leaflets, posters, and recording and reporting on a regular basis. 4 While the implementation of activities in the PIK-R program at SMPN 51 Bandung included peer counseling, extracurricular demonstrations, gathering of administrators and members, member recreation, and outreach counseling to elementary school students confirmed with a permit.

Peer counseling at PIK-R SMPN 51 Bandung was mainly done in class and after the flag ceremony on Monday as a place for students to confide. Some informants mentioned that this counseling was carried out regularly every one or two months. The results of this study indicated that the activities carried out by PIK-R SMPN 51 Bandung have not met the activity indicators at the growing stage because the activities have not used printed media such as posters, etc., but the outreach activity outside of school has met the upright stage. ${ }^{4}$

"We routinely provide information in the field after the ceremony every one or two months. There are counseling activities to the classroom but not routine." (C1)

Facilities, infrastructure, and human resources that need to be fulfilled in the growing stage are a secretariat room, a signboard with a minimum size of $60 \times 90$ $\mathrm{cm}$, a minimum management organizational structure consisting of a supervisor, chairperson, secretary, treasurer, program and activity sections, and a minimum of 2 Peer Educators who have been trained in the substance of the GenRe Program. ${ }^{4}$

This study showed that the PIK-R SMPN 51 Bandung did not have a secretariat room or a signboard. Previously, they had their 
own room, but due to the limited number of classrooms, the secretariat room was converted into a classroom. Thus, PIK-R members at this school had activities in the counseling room or unused classrooms after school. In addition, BKKBN had provided GenRe board games that can be used during gathering sessions.

"There used to be a basecamp on the top floor about 3 years ago, but due to the changed of the school principal and the lack of required classroom, the PIK-R secretariat room was used as a classroom. So, we gathered in an unused classroom." (Co1)

According to information from the chief, there were 14 active administrators from grade 9, three of whom were Peer Educators according to the management structure attachment in the 2018 Decree issued by the principal. At the beginning of the programs' formation, two Peer Educators and Counselors from this school had participated in training from the BKKBN in 2016 which was strengthened by a certificate of participation. The result of this study indicated that the facilities and infrastructure at PIK-R SMPN 51 Bandung were not in accordance with the PIK-R management guidelines because of the limitations of the school In terms of human resources, PIK-R SMPN 51 Bandung was in accordance with the guideline at the growing stage.

In the PIK-R growing stage, there must be collaboration with stakeholders inside the community, for example, the school Principal, as well as the nearest public health center (Pusat Kesehatan Masyarakat, Puskesmas) with PIK-R as a medical reference point. 4 There were several institutions that had a collaboration with PIK-R at SMPN 51 Bandung, including the BKKBN through DPPKB of Bandung, Puskesmas, and National Narcotics Board (Badan Narkotika Nasional, BNN). Based on this information, PIK-R in this school had established partnerships in accordance with the growing stage of the existing guidelines.

\section{Discussion}

HIV prevention amongadolescentsisintegrated into biomedical, behavioral, and structural systems that can be achieved with adequate knowledge. ${ }^{5,6}$ Peer education and counseling are effective tools to promote healthy behavior among adolescents. ${ }^{7}$ However, PIK-R, the peer education and counseling mediation program was only implemented in one junior high school in Bandung. Similar finding were found in Banda Aceh that only 7 out of 47 senior high schools implemented this program and this was due to the lack of youth participation and limited human resources. ${ }^{8}$

The implementation of PIK-R at SMPN 51 Bandung has met the criteria for the growing stage including mastering HIV/AIDS material and delivering it in peer education and counseling activities. These results showed similarities with PIK-R in Sukowono District which carried out activities in the form of counseling for adolescents in the community and school environment. ${ }^{9}$ This indicates that the PIK-R management guidelines are the basis for the implementation of this program. Peer counseling techniques have also been practiced by high school students in Cimahi and Bandung ${ }^{10}$ and junior high school in PIK-R Wijaya Kusuma to raise awareness regarding ARH. ${ }^{11}$ Not only in Indonesia, a peer mentorship program to provide support and knowledge about HIV/AIDS were also carried out among young orphans in southern Uganda. ${ }^{12}$

This study did not assess how the implementation of this program in improving adolescents' knowledge about HIV/AIDS. However, peer education activities on HIV/ AIDS conducted in secondary schools in Nigeria demonstrated its effectiveness in increasing knowledge, attitudes and behavior towards HIV prevention. ${ }^{13}$ The Spanish adolescents HIV prevention intervention, COMPAS, also demonstrated improved outcomes in HIV knowledge and attitudes and condom use intentions. ${ }^{14}$ In North Surabaya, most students acquire knowledge on adolescent reproductive health showed a strong attitude (50\%) towards adolescent reproductive health. ${ }^{15}$ These studies imply that school-based education and counseling such as the PIK-R program has the potential to increase students' knowledge about HIV and reproductive health.

There are several challenges faced by SMPN 51 Bandung in fulfillment of facilities and infrastructure. PIK-R in Karawang schools showed the same problem where they did not have secretariat room. ${ }^{16}$ The use of a game similar to the GenRe board game to deliver educational material called ZIG-ZAIDS had been developed to prevent AIDS and then evaluated for use in adolescents in the study by Schall et al. ${ }^{17}$ in Brazil. The results of this study indicate the ability of games to stimulate the participants' learning abilities in an entertaining way that supports the use of GenRe games in the implementation of PIK-R. Collaborating with other institutions such as BKKBN or NGO at SMPN 51 Bandung is needed 
to improve the quality programs such as in PIK-R SMAN 5 Makassar. ${ }^{18}$

In addition to the minimal number of schools implementing this program, the utilization of this program is also still low. A study conducted at senior high school in Makassar City found that only $24.3 \%$ of the students used adolescent reproductive health services such as PIK-R. Meanwhile, reproductive health knowledge is related to the utilization of these services. ${ }^{19}$ Another study in Bekasi City found that only $54.88 \%$ of students were aware of the PIK-R program and only $8.11 \%$ participated in the program. Similarly, students who participated in the PIK-R program showed significantly lower negative behaviors. ${ }^{20}$ Therefore, the implementation of PIK-R should be more encouraged and supported as an effective way to improve the knowledge and behavior of adolescents.

The limitation of this study is that the data collection which is performed in the only school that is still actively running the PIK-R program while other schools are no longer running the program. Further studies can be done to assess how this program affects the knowledge and behavior of adolescent about HIV/AIDS prevention in Bandung in particular and in others regions in Indonesia in general.

In conclusion, the only PIK-R currently running at junior high school in Bandung, SMPN 51 Bandung, has been implementing the program in growing stage following the PIK-R management guidelines published by BKKBN with all its limitations. This program can be a media prevention of HIV/AIDS among adolescent students and should be implemented in more schools in Bandung. Therefore, the full support of the BKKBN and the school itself is needed to improve the implementation of this program.

\section{References}

1. UNAIDS. Country factsheet Indonesia 2019 [Internet]. 2019 [cited 2020 Dec 4]. Available from: http://www.unaids.org/ en/regionscountries/countries/indonesia

2. Yoshimura K. Current status of HIV/ AIDS in the ART era. J Infect Chemother. 2017;23(1):12-6.

3. Kementerian Kesehatan RI. Situasi dan analisis HIV AIDS. Jakarta: Kementerian Kesehatan RI; 2014. p.1-6.

4. Badan Kependudukan dan Keluarga Berencana Nasional Direktorat Bina Ketahanan Remaja. Pedoman pengelolaan pusat informasi dan konseling remaja dan mahasiswa. Jakarta: Badan Kependudukan dan Keluarga Berencana Nasional Direktorat Bina Ketahanan Remaja; 2014.

5. Hosek S, Pettifor A. HIV prevention interventions for adolescents. Curr HIV/ AIDS Rep. 2019;16(1):120-8.

6. DiClemente RJ, Jackson JM. Towards an integrated framework for accelerating the end for the global HIV epidemic among young people. Sex Educ. 2014;14(5):60921.

7. Abdi F, Simbar M. The peer education approach in adolescents- narrative review article. Iran J Public Health. 2013;42(11):1200-6.

8. Safrizan S, Mawarpury M, Sofia S, Usman S, Sahputra I. Students' knowledge level towards generation planning program in the city of Banda Aceh. STRADA Jurnal Ilmiah Kesehatan. 2021;10(1):10-6.

9. Wahyuningrum DM, Gani HA, Ririanty M. Upaya promosi kesehatan pendewasaan usia perkawinan oleh pusat informasi konseling remaja (PIK-R) ditinjau dari teori precede-proceed. Pustaka Kesehatan. 2015;3(1):186-92.

10. Nurfazriah I, Sunjaya DK, Susanah S. The peer counseling model in adolescents reproductive health for senior high school students. Glob Med Health Commun. 2018;6(3):209-19.

11. Isni K, Matahari R. The role of Wijaya Kusuma's Youth Information and Counseling Center (PIK-R) on adolescent health problems. International Journal of Public Health Science (IJPHS). 2018;7(1):27-32.

12. Nabunya P, Ssewamala FM, Mukasa MN, Byansi W, Nattabi J. Peer mentorship program on HIV/AIDS knowledge, beliefs, and prevention attitudes among orphaned adolescents: an evidence-based practice. Vulnerable Child Youth Stud. 2015;10(4):345-56.

13. Adeomi AA, Adeoye OA, Asekunolarinmoye EO, Abodunrin OL, Olugbengabello AI, Sabageh AO. Evaluation of the effectiveness of peer education in improving HIV knowledge, attitude, and sexual behaviours among in-school adolescents in Osun State, Nigeria. AIDS Res Treat. 2014;2014:131756.

14. Espada JP, Orgilés M, Morales A, Ballester $\mathrm{R}$, Huedo-Medina TB. Effectiveness of a school HIV/AIDS prevention program for Spanish adolescents. AIDS Educ Prev. 2012;24(6):500-13.

15. Muthmainnah M, Nurmala I, Siswantara 
P, Rachmayanti RD. Implementation of adolescent health programs at public schools and religion-based schools in Indonesia. J Public Health Res. 2021. doi: https://doi.org/10.4081/jphr.2021.1954

16. Oon S. Kebijakan pelaksanaan pusat informasi konseling remaja (PIK R) berbasis sekolah di Karawang. Health Science Growth Journal. 2017;2(1):47-62.

17. Schall VT, Monteiro S, Rebello SM, Torres M. Evaluation of the ZIG-ZAIDS game: an entertaining educational tool for HIV/ AIDS prevention. Cad Saúde Pública (Rio de Janeiro). 1999;15(Suppl 2):S107-19.
18. Alyas A. Implementasi kebijakan kesehatan reproduksi. Al-Fikr. 2011;15(1):195-214.

19. Violita F, Hadi EN. Determinants of adolescent reproductive health service utilization by senior high school students in Makassar, Indonesia. BMC Public Health. 2019;19(1):286.

20. Hastuti D, Alifiasari A, Hernawati $\mathrm{N}$, Oktriyanto $\mathrm{O}$, Puspitasari MD. Effectiveness of "PIK-R" program as an extracurricular for high/vocational school students in preventing negative behaviors of adolescents. Cakrawala Pendidikan. 2019;38(1):1-15. 